\title{
The form of texts: possibilities and limitations of an «integral» text- typological model
}

\begin{abstract}
The paper explores the possibilities and limitations of a general text typology within the framework of Coseriu's «text linguistics as a linguistics of sense» (Textlinguistik als Linguistik des Sinns). The investigation draws upon three sources: (i) explicit references to text-typological concepts in Coseriu's work and the internal organization of this field as recoverable from his illustrations and analyses; (ii) an analogy with Coseriu's concept of language type; (iii) a consistent pursuit of the theoretical premises of sense construction and sense articulation. We propose a definition of text type as the form of discourse, i.e. as a functionally distinct layer of textual organization - that of the principles which justify in a unitary way the orientation of sense construction in the individual text, beyond the heterogeneity of the text's constitutive units and strategies. By discussing the presuppositions and consequences of this definition, we aim to ascertain in what way and to what extent it is possible to construct an «integral typology of real texts», as opposed to a mere classification of text-constitutive units, procedures or strategies.
\end{abstract}

\section{Keywords}

Eugenio Coseriu, «integral» text linguistics, sense construction, text type, text genre, category of texts

\section{Résumé}

L'article examine les possibilités et limites d'une typologie textuelle générale dans le cadre conceptuel de la «linguistique textuelle comme linguistique du sens»(Textlinguistik als Linguistik des Sinns). L'investigation s'appuye sur trois genres de sources: (i) les références explicites à des concepts de typologie textuelle dans les travaux de Coseriu et l'organisation interne de ce champ ainsi qu'elle peut être reconstituée à partir des illustrations et analyses effectuées par Coseriu; (ii) une analogie avec le concept de type de langue proposé par Coseriu; (iii) l'élaboration cohérente des prémisses théoriques concernant la construction et l'articulation du sens. Nous proposons une définition du type textuel comme forme du discours, i.e. comme palier fonctionnellement distinct dans l'organisation textuelle - le palier des principes qui justifient de façon unitaire l'orientation du processus de la construction du sens dans le texte individuel, au-delà de la hétérogénéité de ses unités et procédés constitutifs. Par une discussion critique des présuppositions et conséquences de cette définition, nous essayons d'évaluer dans quelle mesure et de quelle manière serait-il possible de construire une «typologie intégrale des textes réels», par opposition à une simple classification d'unités, de procédures ou de stratégies utilisées pour la constitution des textes.

Mots-clé

Eugenio Coseriu, linguistique «intégrale» du texte, construction du sens, type textuel, genre textuel, catégorie de textes

* Emma Tămâianu-Morita (b. 1968) is since 2009 Professor at Akita University, Japan (Chair of International Communication Studies), after having previously worked as Associate Professor at Babeş-Bolyai University, Romania (Chair of General Linguistics and Semiotics). Principal fields of research: text linguistics, with special focus on text typology; contrastive linguistics and translation studies; cultural semiotics. Main books: Fundamentele tipologiei textuale. O abordare în lumina lingvisticii integrale [Foundations of Textual Typology. An Approach in the Light of Integral Linguistics] (Cluj-Napoca: Clusium, 2001), Integralismul $\hat{\imath}$ lingvistica japoneză. Dimensiuni - impact - perspective [Integralism in Japanese Linguistics. Dimensions Impact - Perspectives] (Cluj-Napoca: Clusium, 2002), Limba japoneză. Schiţe de gramatică funcţională [Japanese Language. Sketches of Functional Grammar], 2 vols. (Cluj-Napoca: Clusium, 2004 \& 2006); coeditor of the volume Limbaj primar vs. Metalimbaj. Structuri, funcţii şi utilizări ale limbii [Primary Language vs. Metalanguage. Structures, Functions and Uses of Language] (Cluj-Napoca: Presa Universitară Clujeană, 2008). 


\section{The challenge: finding "the concord of this discord"}

1.1. In W. Shakespeare's A Midsummer Night's Dream, the artisans, self-appointed actors led by Quince the carpenter, enthusiastically prepare to enact the play "Pyramus and Thisbe" at the wedding celebrations of Athen's duke Theseus with the Amazonian Queen Hippolyta. Although the night's misadventures caused by Puck's love potion make the workers miss the happy occasion, the long-awaited chance does come at the end of the day, since Theseus desires to "wear away this long age of three hours" (V:i, 33) before bedtime. On the list of available pastimes, the craftsmen's artistic gift is introduced with the following puzzling characterization,

'A tedious brief scene of young Pyramus

And his love Thisbe, very tragical myrth' (V:i, 56-57)

to which Theseus justifiably reacts:

Merry and tragical? Tedious and brief?

That is hot ice, and wondrous strange snow!

How shall we find the concord of this discord? (V:i, 58-60)

Philostrate, Master of the Revels, dissolves the apparent contradiction, by distinguishing points of view, criteria and levels of interpretation:

A play there is, my lord, some ten words long,

Which is as brief as I have known a play;

But by ten words, my lord, it is too long,

Which makes it tedious; for in all the play

There is not one word apt, one player fitted:

And tragical, my lord, it is;

For Pyramus therein doth kill himself.

Which, when I saw rehearsed, I must confess,

Made mine eyes water; but more merry tears

The passion of loud laughter never shed. (V:i, 61-70)

Interest aroused by this level-headed explanation, and with the broad-minded grace of a true sovereign, despite Philostrate's warning as to the doubtful artistic quality of the amateur enactment, Theseus then decides, "I will hear that play" (V:i, 81).

1.2. Here we have, in a nutshell, the essence of what is at stake in any text-typological undertaking. All textual typologies posit themselves as models apt to evince "the concord of this discord", by clarifying the reciprocal standing of the criteria according to which texts are characterized one way or another, no matter how heterogeneous or even contradictory these may appear at first sight. An analogy that comes to mind is the reconstruction of a puzzle out of a set of disparate pieces. As far as a linguistic text-typology is concerned, however, this task can never be performed in a merely additive or compositional fashion, as if the issue were simply to take the amalgamated pieces of a ready-made puzzle and put them back in their 'proper' order. To maintain the analogy, the cornerstone of a text-typological investigation within the disciplinary boundaries of linguistics is no less than the mind-blowing conundrum of discovering which pieces belong, and which pieces do not belong to a puzzle that is being created as the process of discovery unfolds, with nothing else to go by than an underlying intuition of coherence, to be objectively attested only when the puzzle is complete. In other words, the actual challenge of a linguistic text typology lies not so much in trying to give a 
coherent organization to criteria already found to be relevant, but in discriminating factors, criteria and characterizations that are external to the linguistic perspective proper. It goes without saying that the theoretical outlook adopted as conceptual background for this necessary ground-breaking operation will radically influence the goals, methods and results of any texttypological investigation.

1.3. The problem will reveal itself more clearly if we start from the spontaneous reaction that a layperson may have, when faced with a text at first sight, to a generic question like 'What kind of text / type of text do you think this is?'. For purposes of illustration, I experimented with a group graduate and undergraduate students from a Japanese university and a Romanian university, ${ }^{1}$ presenting them with an excerpt from a genuine English text in the form reproduced below, ${ }^{2}$ and the question "What kind of text / type of text do you think it is?". Students were allowed to read the text at their own pace and write down short answers, either in English or in their native tongue. The explicit instruction was also given that they were allowed to judge the text from various perspectives or according to various criteria, and thus give multiple answers.

(1) Dear friend whoever you are take this kiss, I give it especially to you, do not forget me, I feel like one who has done work for the day to retire awhile [...] An unknown sphere more real than I dreamed, more direct, darts awakening rays about me, So long! Remember my words, I may again return, I love you, I depart from materials, I am as one disembodied, triumphant, dead.

Among the answers given by Japanese students were: letter, letter to his friend(s) left by a man before going to war, ${ }^{3}$ letter of a dying person, poem, descriptive text, speech (i.e. one turn in a dialogue), religious text, advertisement for life insurance, advertisement for a religion expressing reincarnation, melancholic text, romantic text.

Among the answers given by Romanian students we find: farewell letter, suicide note, last words of a person who is dead now, declaration of love, intimate journal addressed to an imaginary reader, sad romantic letter, poem, the thoughts of someone who reached Nirvana.

All the answers revolve around the following main characterizations:

- farewell letter, suicide note (left by someone who believes in reincarnation, someone who is about to die, or by someone who has already reached enlightenment); love letter;

- poetic text;

- religious text;

- declaration of love;

1 At Akita University (Japan) the test was administered by the author (E.T.-M.) between 9-15 October 2012. I am grateful to dr. Magdalena Ciubăncan, who kindly agreed to administer the test in one of her classes at Dimitrie Cantemir Christian University, Bucharest (Romania) on 11 October 2012, and then return to me the answers thus obtained.

2 The fragment is the final stanza of Walt Whitman's poem So Long! (1881), with the material separation into verses removed, in order to avoid the risk of automatic univocal characterization as "poem" based on purely formal clues.

3 It is interesting to note the direct influence of some Japanese cultural context factors in this characterization. No doubt, the familiar topic of WWII soldiers, frequently taken up in the Japanese media, with focus on the controversial issue of the young men who were to become kamikaze pilots, lends coherence to a purely 'factual' interpretation of the text, otherwise impossible in the absence of such a cultural evocation. The image of "awakening rays" "darting" around the speaker reinforces the connection with the perceptual experience of a kamikaze pilot speeding in flight towards death. Thus, being "dead" and "triumphant" is not regarded by the reader, in this case, as a metaphor, but as a statement of fact: the moment a kamikaze pilot received orders to embark on his mission, his fate was sealed, and, in terms of psychological commitment, he was already "dead". 
- advertisement (related to the business or religion of 'death' and 'reincarnation');

- description of the author's feelings ${ }^{4}$;

- part of a dialogue - with an addressee whose identity is not known (perhaps an imaginary addressee);

- sad or melancholic text, i.e. a text written in a grave tonality (as opposed to a funny or 'humorous' text).

It is immediately apparent that all the characterizations above are 'correct', in that they all identify and capture characteristics of the text at different levels and from different points of view. In this sense, it is clear that the typological intuition of speakers does provide a firm basis for the reflexive level of a text-typological investigation, and at the same time, that it raises the need to deal with the extreme heterogeneity of the characterizations. In a tentative ordering that goes from the inner rings of the text's internal constitution to the outer rings of the text's context and purpose of use, the following different levels and perspectives can be detected (Table 1).

\begin{tabular}{|l|l|}
\hline \multicolumn{1}{|c|}{ Characterization } & \multicolumn{1}{|c|}{ Corresponding level / perspective } \\
\hline 'description' & $\begin{array}{l}\text { textual expression (Textkonstitution, the units and } \\
\text { functions that make up the text and serve as support } \\
\text { for its sense) }\end{array}$ \\
\hline (part of a) 'dialogue' & $\begin{array}{l}\text { textual expression: a device pertaining to the } \\
\text { universal level of speech in general is taken up as } \\
\text { part of the individual text's constitution }\end{array}$ \\
\hline $\begin{array}{l}\text { [text about] 'love', 'religion', 'Nirvana', } \\
\text { 'reincarnation', 'farewell' }\end{array}$ & $\begin{array}{l}\text { designation of textual units (what the text 'speaks } \\
\text { about') }\end{array}$ \\
\hline 'poetic' & $\begin{array}{l}\text { textual sense: the construction of sense in a fashion } \\
\text { that does not observe the rules of everyday } \\
\text { experience and for which the laws of empirical } \\
\text { reality are irrelevant }\end{array}$ \\
\hline 'sad', 'melancholic', 'romantic' & $\begin{array}{l}\text { textual sense: a superordinate layer understandable } \\
\text { as overall 'tonality' or 'atmosphere' }\end{array}$ \\
\hline 'letter', 'intimate journal' & $\begin{array}{l}\text { relation with the tradition of texts: textual genres, } \\
\text { recognized on the basis of either traditional devices } \\
\text { (ex. the opening formula "Dear friend" in a written } \\
\text { text) or content clues (the addressee is unknown, } \\
\text { perhaps imaginary, therefore the 'I' is in fact } \\
\text { writing a diary) }\end{array}$ \\
\hline
\end{tabular}

4 A more perceptive reader might have added: "description given as justification for a request" - the request to be remembered after death. This idea does appear, albeit in a looser formulation, in the answer given by one Romanian student: farewell letter by "someone who doesn't want to be forgotten".

5 The status of this superordinate layer in the articulation of sense can be grasped more easily if we place it in analogy with the status occupied by the "ontic significatum", as the fifth and highest type of significatum, in Eugenio Coseriu's model of the idiomatic structuring of semantic units (Coseriu 1989: 43-45). 


\begin{tabular}{|l|l|}
\hline 'suicide note', 'advertisement' & $\begin{array}{l}\text { external perspective, capturing the pragmatic } \\
\text { circumstances and hypothetical purpose for which } \\
\text { the text is (/might be) used }\end{array}$ \\
\hline
\end{tabular}

Table 1: Levels of typological characterization for sample text (1)

What we have here is indeed a wealth of material to work with, and yet, no matter how 'correct', valid or relevant such characterizations may be, they cover at the same time too much and too little: on the one hand, not all of them can justifiably be dealt with as part of a linguistic text-typology; on the other hand, we feel there is more to the typological organization of an individual text than can be rendered through any such labels, even when taken in conjunction. Hence, the need for a new - different - perspective in defining the concept of text type.

\section{Starting point and theoretical background of the present proposal}

The framework adopted for this discussion is Eugenio Coseriu's «text linguistics as a linguistics of sense» (Textlinguistik als Linguistik des Sinns), and my primary purpose is to sketch the main dimensions of a general text typology, while at the same time exploring its possibilities and limitations. The term "integral linguistics", advanced by Eugenio Coseriu to designate the triadic conception of language he developed starting from the 1950 s, ${ }^{6}$ will be used throughout this paper in this acceptation; the adjective "integral" will henceforward be employed in this precise (restricted) sense and without quotes.

To my knowledge, Eugenio Coseriu's work published up to the present moment does not provide a fully elaborated or 'final' outlook on the issue of text typology. Nevertheless, in several fundamental works, such as the monograph on linguistic competence (Coseriu 1988) and the volume on text linguistics (Coseriu 1981), we do come across a whole series of concepts and examples pertaining to the field of typology. The illustrations below are selected from Sprachkompetenz (1988).

(a) Textsorten - news (p. 256), tale (p. 256), example (p. 55);

(b) Textarten - sonnet (p. 161, p. 171), syllogism (p. 161, p. 171), news (p. 171);

(c) Textformen - greeting (p. 164), reported speech (p. 168).

To these we should add the term Gattungen (e.g. Coseriu 1981: 118), referring to 'textual genres' (including literary genres).

Naturally, such examples stem from a preliminary intuition about the articulation of this field, and this, I believe, also explains certain terminological oscillations. More importantly, however, one must be aware that all of these terms and the discourse realities they cover must be interpreted from the standpoint of Coseriu's general outlook on language understood as a creative activity, and do not necessarily coincide with the way they are used in other theoretical orientations.

Consequently, the construction of an integral text typology can draw upon three main sources:

For the justification of this term and an analysis of its implications, see Kabatek / Murguía (1997, Ch. 7, esp. pp. 158-163). 
(i) explicit references to text-typological concepts in Coseriu's work (such as Textsorten, Textarten, Textformen, Gattungen), and the internal organization of this field as recoverable from Coseriu's illustrations and analyses;

(ii) suggestions from an analogy with Coseriu's concept of language type;

(iii) consistently following through the theoretical premises of sense-construction and sense-articulation as laid out in the delineation of text linguistics as a linguistics of sense.

The considerations that follow reflect a personal quest on the grounds of this theoretical outlook, unfolded over almost two decades, the results of which were first systematized in Tămâianu 2001, and subsequently developed and illustrated in other contributions, such as Tămâianu-Morita 2002 (esp. chapters 5 and 6), 2005, 2006a, 2006b, 2006c, 2007, 2012. ${ }^{7}$

The focus of the present paper lies in defining what «text type» can be, and, perhaps more importantly, what «text type» cannot be, if what is sought for is an «integral typology of real texts», as opposed to a mere classification of text-constitutive units, procedures or strategies. I will therefore state from the very beginning that what interests me is to probe into the alternative of a non-taxonomic typology, i.e. a typology that does not represent a classification of texts, and is not obtained on the basis of 'abstracting' general features and combining them into ideal constructs.

\section{An analogy: Coseriu's concept of language type}

3.1. In order to examine whether such a text typology is, at all, conceivable and also practically feasible, the most pertinent clues can be found in an analogy with the idea of a typology of languages as proposed by Coseriu. ${ }^{8}$ On the one hand, Coseriu's criticism and analysis of the limitations of current approaches in language typology can be applied, mutatis mutandis, to numerous text-typological models as well. ${ }^{9}$ On the other hand, the definition of language type in "the integral typology of real languages", with all of its theoretical and methodological consequences, delineates an analogical framework from which ample benefits can be derived for designing the investigation of text type proper. Thus, textual typology will also be a "real" and "integral" typology in the sense made clear by Coseriu with regard to language typology (1983a: 274). ${ }^{10}$

3.2. Coseriu first identifies an approach that he describes as "partial morpho-syntactic typology", which yields "typologies of linguistic means (devices)", working with 'types' such as: SOV/SVO languages, ergative/accusative languages, languages with or without article. ${ }^{11}$ In this approach, the 'type' is actually a class of languages defined through certain isolated

7 The view on text typology presented here was developed independently from a significant enterprise with a similar aim, that of Oscar Loureda (see, for instance, Loureda 2002, 2003, 2006), and the distinctions advocated here point towards a somewhat different path of elaboration. On many individual issues, however, our positions are similar or at least compatible. Further debate will undoubtedly result in important terminological and conceptual clarifications, so that a fully coherent solution be found for the benefit of future typological investigations starting from the framework of Coseriu's text linguistics.

8 Numerous Coserian studies are devoted to the issue of language typology, from both theoretical and applicative angles. Some of the most important are listed in the bibliography (1968, 1979b, 1983a, 1987b).

$9 \quad$ For a succinct discussion, see infra, 6.

10 The significance of this perspective and its radical differences to existing text typologies of other theoretical orientations were analysed in detail in Tamâianu 2001: 49-59, 61-90.

11 For the partial morpho-syntactic typology, see Coseriu 1983a: 270-271, 275, 1979b: 39-43, 1987b: $238,241$. 
features which are given the privileged status of typological criteria. ${ }^{12}$ The classes are therefore obtained by operating cross-sections through "real" (authentic) languages.

A second approach, the "global morpho-syntactic typology", yields "global" and "abstract" typologies of methods of linguistic structuring, ${ }^{13}$ working with 'types' such as: inflectional, agglutinative, isolating, incorporating. In this approach, the 'types' are in fact sets of procedures, ideal composite constructs that cannot be found as such in real languages, but simply manifest themselves (are realized) in languages to a greater or lesser extent. ${ }^{14}$

Since none of these approaches can accurately reflect the structuring of any one "real" language, i.e. a language as it is in its historical individuality, Coseriu advances a reinterpretation of the notion of 'language type', in the framework of what he terms "the integral typology of real languages":

Für die partielle Typologie ist der Sprachtypus eine K la s s e v o n $\mathrm{S} \mathrm{p} \mathrm{r} \mathrm{a} \mathrm{c} \mathrm{h} \mathrm{e} \mathrm{n,} \mathrm{die} \mathrm{durch} \mathrm{gewisse}$ Einzelmerkmale (mit denen eventuell andere zusammenhängen) oder auch nur durch ein einziges Merkmal abgegrenzt wird. Für die Typologie der abstrakten Sprachgestaltungsmethoden ist ein Sprachtypus ein I d e a l k o n s t r u k t, das sich in den historischen Sprachen in jeweils verschiedenem Ausmass realisiert. Für die integrale Sprachtypologie der realen Sprachen ist hingegen der Typus eine E $\mathrm{b}$ e $\mathrm{n}$ e der inhaltlichen und materiellen $\mathrm{S} \mathrm{t} \mathrm{r}$ u k t u r i e r u n $\mathrm{g}$ einer jeden Sprache oberhalb der Ebenen der Sprachnorm und des Sprachsystems. (Coseriu 1983a: 274)

In this new definition, 'language type', defined with explicit reference to Humboldt's "charakteristische Form", represents:

[...] die Ebene der Typen und Kategorien von Funktionen und Verfahren, der einheitlichen Prinzipien der inhaltlichen und materiellen Strukturierung einer Sprache (1983a: 274);

[...] la couche de l'analogie structurale et fonctionnelle entre les différentes sections d'un système, la couche de l'unité supérieure des fonctions et des procédés d'une langue. [...] il correspond aux principes de structuration d'une langue et représente sa cohérence et son homogénéité fonctionnelle, sous-jacentes à la variété et diversité des fonctions et des procédés spécifiques au niveau du système. (Coseriu 1987d: 53$54)^{15}$

If the type is thus understood as a layer of principles that reflect an underlying internal consistency in the functional organization of a language,

[...] un principe vraiment typologique devrait s'appliquer, mutatis mutandis, à n'importe quel niveau de structuration de la langue. (Coseriu 1987d: 59)

This second statement actually suggests a methodological path for discerning and testing the validity of candidate typological principles: every such principle should be all-encompassing, apt to explain configurations and devices of diverse natures and situated at different levels of the text's constitution.

3.3. I therefore believe that in building up a Coserian text typology we have to start from the fundamental question whether it is possible (or, in stronger form, whether it is necessary) to identify, for text/discourse as the autonomous level of sense construction, a specific layer of structuring to be defined in a similar way. In other words, is it possible / necessary to conceive 'text type' not as a 'class of texts' or as an 'abstract pattern', but as a structuring layer of the

Cf. Coseriu 1983a: 274, 1987b: 238, 241.

For the global morpho-syntactic typology, see Coseriu 1983a: 275, 1987b: 237-238.

Cf. Coseriu 1983a: 273-274.

The same definition can be found in Coseriu 1968: 195. 
individual text itself? In what follows I will try to outline a tentative answer derived from the principal theses that define the domain of text linguistics as a linguistics of sense.

\section{Text type - a provisional definition within the perspective of integral text linguistics}

4.1. In integral linguistics the whole issue of textual typology must be placed in the horizon of language as an activity of creation of meaning, based, at each level of manifestation (universal, historical, individual), on a specific competence (elocutional, idiomatic, expressive) and resulting in specific products, subjected to specific judgements of conformity (congruence, correctness, adequacy). ${ }^{16}$

This triadic framework, which represents the foundation of integral linguistics as an "objectively grounded" theory of language, was developed by Coseriu starting from two "general observations" (1955-56: 285-287, 1988: 70-71):

(A) that language is (1) a generally-human activity (Tätigkeit), carried out by individuals

(2) as representatives of communitary traditions of speech competence (Sprechen-können)

(3) at an individual level;

(B) that any cultural activity, including the activity of speaking, can be regarded (a) as activity as such (enérgeia), (b) as the knowledge or competence underlying the activity (dynamis), and (c) as the product of that activity (ergon).

The two triads ( 3 levels of manifestation and 3 points of view) delineate nine aspects of language as a creative cultural activity, aspects which, according to Coseriu, can also be found as such in the intuitive knowledge of speakers.

\begin{tabular}{||l|c|c|c||}
\hline VIEWPOINT & Activity & Knowledge (Competence) & Product \\
LEérgeia & dynamis & ergon \\
\hline $\begin{array}{l}\text { Universal } \\
\text { Speaking in general } \\
\text { (universally-human } \\
\text { activity) }\end{array}$ & Speech in general & Elocutional & $\begin{array}{c}\text { Empirically infinite } \\
\text { totality of utterances }\end{array}$ \\
\hline $\begin{array}{l}\text { Historical } \\
\text { Particular languages } \\
\text { (idiomatic traditions) }\end{array}$ & Concrete language & Idiomatic & [Abstract language] \\
\hline $\begin{array}{l}\text { Individual } \\
\text { Discourse / Text } \\
\text { (individual speech) }\end{array}$ & Discourse & Expressive & Text \\
\hline
\end{tabular}

Table 2: Levels and aspects of language as a creative cultural activity

16 For the outline given below, see Coseriu 1955-56: 285-287, as well as the systematizations in Coseriu 1973/1981, chapter X, and Coseriu 1988: 59, $70-75$ (with the table at p. 75 - translation mine, E.T.-M.). For the evaluations of speech at each level, see especially 1981: 41-43; for the subcategorization of the judgments of adequacy (Angemessenheit), the value specific of the level of discourse, see also 1988: 179-181. 
In this framework, the principles of text-typological organization should be conceived as a functionally distinct level or component of expressive competence.

In fact, an explicit suggestion as to the mutual relations of the various text-typological concepts mentioned above, in section 2., appears precisely in the context of a debate about the nature, content and structuring of linguistic competence at the level of the individual activity of speaking (i.e. expressive knowledge or competence). Similar to elocutional knowledge, expressive knowledge is structured "in the broad acceptation of the term", i.e. it presents "a certain form of internal relationships" (Coseriu 1988: 262). It is not necessarily structured, however, "in a narrow sense", i.e. the form of internal relationships is not characterized by homogeneity and "rigidity" (Festigkeit), but comprises diverse and variable dimensions (Coseriu 1988: 259). The "loose" character of textual norms should not be taken in a superficial or circumstantial sense of 'optional applicability' or higher dependence on personal idiosyncrasies. The 'looseness', the lack of rigidity, reflects their multifarious nature: textual norms may concern form or content, may have diverse degrees of specificity, may operate on different types of units, may be effective in smaller or larger numbers for each textual genre/category etc.: ${ }^{17}$

Das expressive Wissen ist [...] enorm verschiedenartig, und die entsprechenden Normen sind von ganz unterschiedlicher Verbindlichkeit. Sie reichen von den ganz allgemeinen Normen für die verschiedenen Arten des Sprechens [modalities of speech] über präzisere Normen für Textsorten [text categories] bis hin zu den sehr präzisen Normen für die Strukturierung bestimmter traditionell fixierter Textformen [text forms]." (Coseriu 1988: 159)

4.2. Discourse / Text is defined, in integral linguistics, as the autonomous linguistic level of sense-construction, in which the significata and designata of linguistic units become a new, second degree, signifier - a signifier for textual sense. In Textlinguistik, this double semiotic relation at the level of texts ${ }^{18}$ is schematically represented as follows (Coseriu 1981: 48):

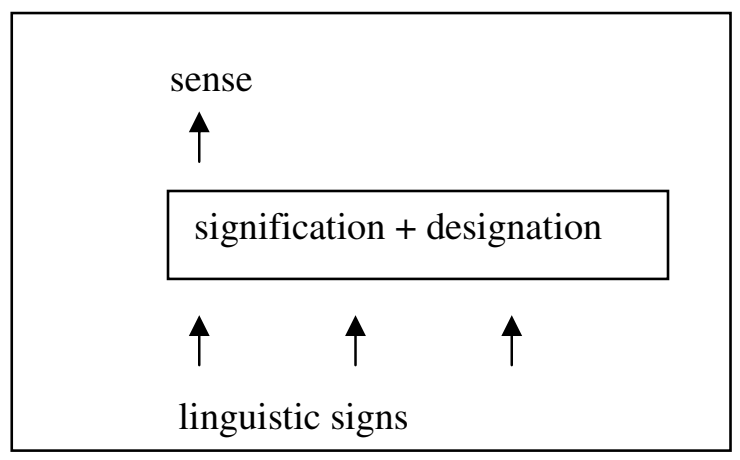

Scheme 1: The double semiotic relation in texts

17 Looking at the same phenomenon from a different angle, Kabatek (2005a, 2005b) also emphasizes the diversity and variability of textual elements (certain textual finalities or certain formal characteristics) that can serve as a basis for the formation of discourse traditions, through repeatability in texts. In particular: "La répétibilité de formes textuelles comprend une échelle continuelle de marcage de tradition minimaux - p. ex. une certaine dénomination de texte ou une formule dans un texte qui par ailleurs n'est pas fixé dans la tradition -, l'organisation formelle et le fixement définitif d'un texte." (2005a: 152; see also 2005b: 157) The relationship between a given text and a textual tradition "est graduel: un sonnet est une forme fortement prédéfinie, une conversation informelle dans un bar, par contre, semble être beaucoup plus ouverte et moins fixée sur une tradition textuelle." (2005a : 154)

18 See especially Coseriu 1973/1981, chapter X, 7.3., 1981: 48-50. 
Scheme 1 should not be interpreted as a fixed configuration of necessary and sufficient elements that make up a text in a concrete fashion, but merely as a simplified representation of the semiotic mechanism of the double articulation of meaning at the level of texts. A more direct formulation, focused on the mechanism as such, is proposed in Scheme 2.

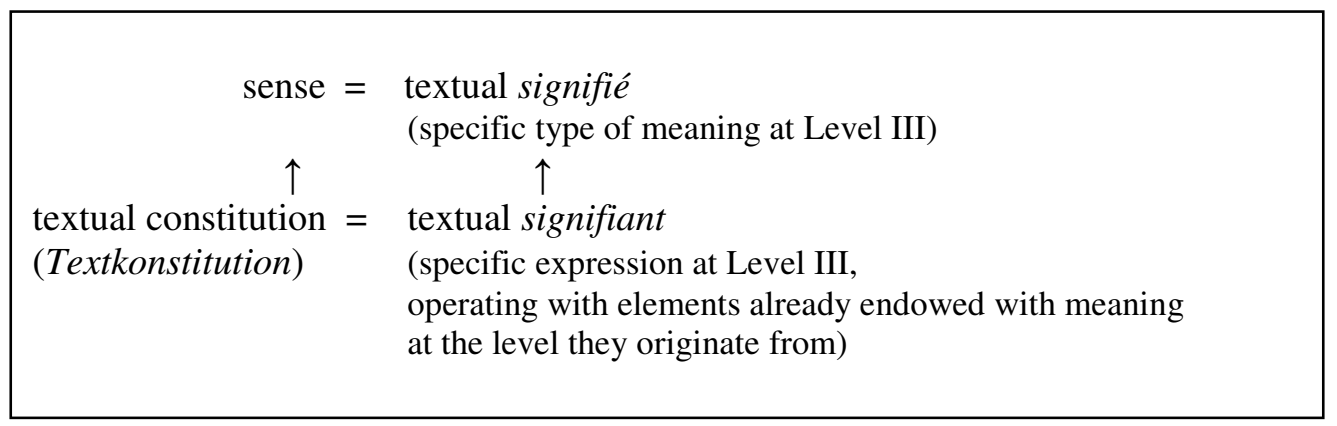

Scheme 2: The double semiotic relation viewed as the semiotic mechanism of sense-construction

I have argued elsewhere ${ }^{19}$ that, in a text-linguistic model built on Coserian bases, we can conceive the expression of texts (Textkonstitution) as being represented by two categories of elements, which I have proposed to dissociate into «text-constitutive units» and «textconstitutive procedures/devices», according to the way they are situated in relation to the individual text in which they appear. On the one hand, the units we may describe as pre-textual, in the sense that their identity is established prior to the construction of the individual text: some are given at the elocutional and idiomatic levels (Levels I and II in Coseriu's triad), while others come from the historical traditions of texts (text genres), and are taken up as such, in the quality of raw material, so to speak, for the construction of a new text. On the other hand, textconstitutive procedures / devices capture what is being done with the units in the individual text, and cannot be reduced to devices or strategies from the elocutional or idiomatic levels. ${ }^{20}$

If we adopt this understanding of texts, as defined through the process of senseconstruction, methodologically accessible by the analysis of textual constitution in relation to (interpreted) textual sense, it follows that the typological layer of "real" texts can only be defined as the modality ${ }^{21}$ of sense-construction in each given text: the modality in which the significations and designations of textual units become a signifier for textual sense, and the modality of internal sense-articulation (Gliederung des Sinns).

19 Tămâianu 2001: 40-41, 125-133, 2009, 2012.

20 Based on Coseriu's theoretical considerations and text analyses, I have systematized a tentative list of elements that may qualify for the status of text-constitutive units and procedures in an integral text lingustics. The list is provisional and open to further expansion.

A. Text-constitutive units: (a) idiomatic signs, ranging over all the strata of idiomatic organization and comprising all the five types of significata, with the constellation of all their relations at the idiomatic level; (b) traditional means for realizing specific textual functions (for example, formulae for the beginning and end of given text genres); (c) previous (fragments of) texts taken up as such and used as raw material for the constitution of a new text.

B. Text-constitutive procedures: (a) evocative sign relations (Coseriu 1971/1977: 201-202, 1981: 68-101, 1987a: 25-29) ; (b) textual functions (as defined in Coseriu 1981:45-47, 170-174, 1987c: 15); (c) forms of suspending incongruence and incorrectness through the value of adequacy; (d) expression "gaps" (Ausdruckslücke, as defined in Coseriu 1987e).

21 The term 'modality' is used here in the same acceptation as in Coseriu's definition of the particular language (Einzelsprache) as a historically determined modality of speech (Coseriu 1988: 74), reflected in "adverbial formulations" like "Latine loqui", "deutsch sprechen", "a vorbi româneşte" (lit. "to speak in the Romanian fashion'). 
The direct consequence of this understanding is that no 'surface structure', 'local' strategy, 'semantic-syntactic macrostructure' etc. materially identifiable in a text will delineate in and by itself the typological level, as these reflect only the text's constitution (Textkonstitution), or textual signifier. Text typology will begin only from a subsequent moment, so to speak: it will begin with the modality in which the sense corresponding to this signifier is instituted.

4.3. To illustrate this point, let us consider the issue of the fixed formulae for the beginning of texts, starting from Coseriu's observations (1981: 141-147) on idiomatically fixed phrases correlated with certain categories of texts, ${ }^{22}$ such as Engl. "once upon a time", specialized for the textual function of «initiating a fairy tale». Even for one and the same formula, however, its textual role can be very different in different texts, Coseriu notes, since the formulae can be employed "literally" or "metaphorically", in "serious" register or ironically etc. It is only when we take into account interpretations of this nature that we can speak of the textual level proper (the level of sense-construction), whereas the formulae in themselves, with their lexical and grammatical structure and even with the prevailing textual function which is associated to them by tradition, are pre-textual constitutive units, in the sense delineated in section 4.2. (they precede the creation of the given individual text and are taken up as raw material for its constitution).

Effecting a typological characterization based on such a constitutional unit, by saying, for instance, that texts beginning with "once upon a time" are (/may be) fairy tales, yields a typology very similar in nature to the "partial" morpho-syntactic typology of languages, or, if a systematic correlation with other constitutional features is found, to the "global" typology of methods of linguistic structuring, at best. It is not my intention to deny the validity or usefulness of such text typologies; what I want to suggest is that it is possible to go beyond them, and subsume such constitutional devices to sense functions and principles of sense construction apt to delineate a typological layer of the individual text similar in nature to Coseriu's integral language type.

Let us now turn to the same poem that was used at the beginning of this paper, namely Walt Whitman's, So Long! (1881), which opens with the line:

(2) To conclude, I announce what comes after me.

At the level of the traditional means for realizing certain textual functions, the phrase to conclude is, without a doubt, a device for «signaling the end» of a process or event (for example, reaching an agreement or understanding at the end of a process of negotiation), or «introducing the conclusion» of a text, and certainly not a device for «initiating» an event or a discourse. In other words, it would be an error to maintain that to conclude is a traditional means for realizing not only the function of ending or «wrapping up» a text, but also for «beginning» a text. In Whitman's poem, the phrase to conclude, with its traditional correlation, is taken up as a building block to constitute the textual procedure of «beginning with the conclusion». This procedure is not, in itself, a unit of sense; it is merely the signifiant of a unit of sense, a sense that can only be justified in this individual text and nowhere else. In the poem So Long!, the unit has the sense function of evoking a missing part of the text, or perhaps a whole previous text which remains unexpressed, and the content of which must be

22 The wider issue here is that of the traditional means for realizing certain textual functions, given at the historical level of linguistic competence (i.e. as part of the idiomatic knowledge, not as part of the expressive knowledge), discussed at length in Coseriu 1981: 154-176 and 1988 : 168-169, 256-259. Concerning the issue of "texts incorporated in the idiomatic tradition", see also Óscar Loureda's clarifications in the Spanish 
imaginatively retrieved by the reader. Clues as to what the content of this previous (fragment of) text may be come from the twofold designation of the verb to conclude (achieving a process and drawing the conclusion of a discourse), maintained and enhanced by the rest of the poem: the missing (unexpressed) part to which the actual poem So Long! comes as a conclusion is a discourse posited as coextensive to life itself.

This interpretation stems from the relations between the unit "to conclude" and the other constitutional units of the text. To mention only two of the most obvious:

(a) The main actions of the poetic "I" are verbal actions (say, sing, announce $)^{23}$, and, as he speeds up towards the end, the process of dying is equated to an increment in "meaning". ${ }^{24}$

(b) The passing away takes place in the form of a fading-away into words and sounds ("whispers of myself bequeathing", "a melodious echo"), until, in the final moment, the ultimate unification between man and discourse is effected: the "I" emerges from behind the words, only to release materiality again, by merging with (or being engulfed by) the reader, thus becoming pure meaning, active (alive, so to speak) in the mind of the interlocutor. ${ }^{25}$ It is this consummate merging that justifies the image of the triumphant disembodiment in the final stanza, with the "friend" revealed as any prospective reader of the poem, who will simultaneously, by the act of reading, witness, testify to, and validate the life that the poem alludes to. ${ }^{26}$

All of these interconnected sense units attest that, at the level of sense, the procedure of «beginning by the conclusion» has the function of evoking an absent (part of the) text, posited as co-extensive with life itself.

Naturally, there is no constant and univocal correlation between the unit to conclude (or «to begin a text by the conclusion») with the function «suggesting the existence of a previous text left unexpressed and posited as coextensive with life itself». Thus, there is no conceivable way in which such a correlation can be predicted or automatically identified by the simple presence of certain units of expression. For example, it is easily conceivable that the same phrase placed in the same material position in another text may carry the function of «refusing the dialogue $a b$ initio». Therefore, in order to discover the principles of typological structuring in Whitman's text in the framework of an integral text typology, what is pertinent is not the constitutive unit "To conclude, I announce what comes after me" in itself, but the actual (to use Coseriu's term, "real") function it performs at the level of sense in this individual text.

4.4. Taking the definition suggested under 4.1. one step further, it can be pointed out that text type is neither 'deeper' than observable textual units, structures or procedures, nor 'prior' to the discourse process in any chronological sense, but represents the form of discourse, in the Humboldtian sense of the term. ${ }^{27}$

As Coseriu points out,

version of Textlinguistik (especially footnotes 115 and 116, pp. 138-139).

23 "I have press'd through in my own right, /I have sung the body and the soul [...] // I announce natural persons to arise, / I announce justice triumphant, / I announce uncompromising liberty and equality [...]"

24 "O thicker and faster - (So long!) / O crowding too close upon me, / I foresee too much, it means more than I thought, / It appears to me I am dying."

25 "My songs cease, I abandon them, /From behind the screen where I hid I advance personally solely to you. // Camerado, this is no book, / Who touches it touches a man, / (Is it night? are we here together alone?) / It is I you hold and who holds you, / I spring from the pages into your arms - decease calls me forth."

26 "Dear friend whoever you are take this kiss [...] / I am as one disembodied, triumphant, dead."

27 See Humboldt 1836/1988: 51-53 for the concept of form, and 168-181 for the distinction between the poetic and prosaic modes of discourse. Concerning the relational character of form, see also Coseriu 1979a: 5-6. 
'forma' significa constantemente en Humboldt una sola cosa, a saber, «aquello que estructura o organiza algo»: «lo estructurante» («formante») con respecto a «lo estructurado» («formado»). (1969: 113)

Out of the three acceptations distinguished in this study (1969: 113-116) according to the level where the concept of «form» is applied, ${ }^{28}$ of special interest for the present discussion is the third acceptation, namely the concept of form applied to the internal idiomatic relationship between the specific facts of a language and the principles which underlie those facts. At this level, linguistic form appears to be the organic principle for the structuring and historical development of each language. This is the definition that Coseriu systematically develops and elaborates into the integral concept of language type. A similar definition of text type, as the «form of discourse», is justified, in my view, precisely by the analogy with the typology of languages suggested above.

4.5. The proposed definition of text type as the form of the text, i.e. as the modality of sense construction, is based on two theses: (i) the functional autonomy of language and (ii) the primary nature of the signifying function in relation to the ulterior determinations of speech (Coseriu 1967: 64). As far as discourse is concerned, the specific task of text linguistics is to explain the possibilities of sense construction found in language itself, at the level of the signifying function with its inherent determinations, and not the external determinations through circumstantial factors. ${ }^{29}$ From this standpoint, an external typology, where texts are classified according to the social situation or institutional contexts in which they are used cannot represent, strictly speaking, a textual typology, and cannot be constructed in the framework of a text linguistics, precisely because such a typology merely comes down to a classification of social situations or institutions, which other disciplines are more qualified to offer.

The finality (purposiveness) that belongs to the essence of language is the signifying finality, by virtue of which language is defined as logos semantikos. However, pure semanticity is never given concretely: in discourse acts, logos semantikos is necessarily determined (or actualised) through discourse-specific orientations or finalities. The primary orientations can be discussed, for instance, in terms of the Aristotelian triad of the "apophantic", the "pragmatic" and the "poetic", as developed by Coseriu (1948: 3, 1957: 247, 1987c: 11). Within the boundaries of the present article we cannot go into a critical discussion of this model or alternatives to it. Suffice it to say that, no matter what model will be used, emphasis should be laid on distinguishing on the one hand those orientations which are inseparable from the process of discourse construction ("intentions" or "attitudes" of the subject in the sense discussed below), and on the other hand 'purposes' or 'goals' understood as covering either psychological processes or external aims in the domains of practical action.

From this point of view and in this particular sense, the characterizations of sample text (1) as a "suicide note", "advertisement for life insurance" or "advertisement for a religion which preaches reincarnation" (cf. supra, 1.3.) are all effected by the application of external criteria hypothetical practical purposes for which the text may be used, or hypothetical psychological

28 The other two acceptations regard the relation of language and languages to extralinguistic reality: (a) language in general is the «form» of the apprehension of reality, the «form» of the intuition of the world; (b) each historical language is a distinct «form» of this apprehension, which is expressed in a specific organization of significata.

I refer here not only to contingent factors of a social, political, ideological nature etc., but also to ulterior motives of the individual speaker in a given practical situation. For example, someone may create a poetic or a scientific text with the clear (discourse-external) goal of obtaining financial gain - but such a goal, even when attestable by objective evidence, remains outside the scope of text-linguistic investigation, and will 
motivations of the text's author. Although the existence of such factors is undeniable, their study does not fall within the scope of the proper object of (text) linguistics. ${ }^{30}$

By contrast, the apophantic, poetic or practical orientations reflect the speaker's "intention" or "attitude" in given discourse acts (Coseriu 1957: 238-239), and are, as such, inseparable from textual sense. In more precise terms, they represent the impulse and direction in which the process of sense-construction unfolds:

[...] todo discurso, todo lo que se dice, tiene no sólo designación y significado, tiene también sentido. Se dice algo, para manifestar una actitud, para establecer relaciones particulares con el interlocutor, etc. (Coseriu 1987a: 22-23)

La simple referencia a las cosas, el prescindir precisamente de actitudes, también esto es una actitud; es la actitud de presentar las cosas objetivamente, como son. El sentido no falta nunca. (Coseriu 1987a:23)

Terms like "intention", "attitude" or "relation with the interlocutor" do not concern psychological or pragmatic states, orientations and processes, but intentions and relations of the speaking subject exclusively as a subject with a view to his/her own speaking. Coseriu's example of such an "attitude", quoted above, can serve to clarify this point: the attitude of merely referring to things as they are, of presenting states of things objectively, i.e. the attitude of constructing a sense which tends to coincide with the significata and designata.

\section{Levels of textual form}

5.1. In a Humboldtian interpretation, form has a relational character. It is then to be expected that textual form should also manifest itself not only as first degree form, but also as second or higher degree forms. Text analyses carried out until now led me to believe that it is necessary to distinguish clearly at least between three layers of textual form.

For capturing the first degree form of texts, for which a possible term is 'discourse mode' or 'modality', one can choose between two points of view, or perhaps use them in a complementary manner.

5.1.1. One is the standpoint of the way in which sense units are "articulated" in the text (die Gliederung des Sinns). In this perspective, the first degree form will correspond to the most basic modalities of sense construction (Arten von Sinn). If these are defined starting from Humboldt's distinction between the "poetic" and the "prosaic" modes of discourse, ${ }^{31}$ then they will range between a pole of speaking in poetic modality (sense construction with maximal leap from the significata and designata of textual units), and a pole of speaking in "objective" modality (sense construction with minimal leap, i.e. sense that tends to coincide with the significata and designata of textual units).

therefore not constitute a legitimate criterion of categorization in a linguistic typology of texts.

30 It is in this sense that Coseriu states, for example, that "political texts" cannot represent an autonomous class for text linguistics as a linguistics of sense, since they are separated as such only by virtue of their extralinguistic content and contexts of use (1987c, 2.3.3.).

31 For the distinction between the "poetic" and the "prosaic" modes, see Humboldt 1836/1988: 168-181. While it is true that Humboldt's description of the "poetic" and the "prosaic" modes is intuitive and non-technical, never developed into a full-fledged explanation, a convincing model of the poetic mode of discourse along this line of thought is proposed by Borcilă (1987: 186, 1997a, 1997b), who defines poesis through a "nuclear metaphorical process", and proposes a detailed semantic analysis of its various stages and components. Within the boundaries of text linguistics, from a methodological point of view the "full functionality of language" (Coseriu 1987a: 24-25, 1981: 109-111) can be evidenced through the complexity of the configurations of sign relations and "evocative" functions in the text (1981: 68-102). 
Understood in Humboldtian vein, both modalities represent exponential manifestations of the expressive possibilities of language: the former, oriented towards the full realization of language as logos semantikos, independently of the values of truth and falseness, of correspondence or mismatch with the empirical world; the latter, oriented towards expressing the configuration of objective reality, towards speaking truthfully of things as they are.

My characterisation of the two poles, using the metaphor of a "leap" from the base ground of significata and designata towards the level of sense, is founded on the peculiar manner in which Coseriu emphasizes the idea that all texts have sense, by explaining purely factual discourse through the "coincidence" of sense with the significata and designata:

La simple referencia a las cosas [...] presentar las cosas objetivamente, como son. [...] de este sentido objetivo, que coincide con el significado y con la designación, no nos damos cuenta normalmente porque no es ningún sentido particular, sino la limitación a esto mismo. Lo advertimos cuando pedimos más información, o cuando suponemos otro sentido, demás de este objetivo que coincide con la designación y con el significado. [...] una simple comu nicación sobre los hechos" (Coseriu 1987a: 23) ${ }^{32}$

Naturally, "coincidence" should not be understood as functional identity, but merely as a tendency towards minimal semantic distance between the two, in the model of the double semiotic relation at the level of texts, as given in Scheme 1 (4.2.).

To illustrate this first layer of form, one can take two texts that would be classified, according to external criteria, as belonging to completely different genres. The first is Lewis Carroll's Sorites (1896), a collection of 60 polysyllogisms with between 3 and 10 premises, given in mixed order, so that for solving each sorite one must first reconstruct the correct order and then infer the conclusion. Below is one example from the collection (Sorite 54).

(3)

[1] No shark ever doubts that it is well fitted out;

[2] A fish, that cannot dance a minuet, is contemptible;

[3] No fish is quite certain that it is well fitted out, unless it has three rows of teeth;

[4] All fishes, except sharks, are kind to children;

[5] No heavy fish can dance a minuet;

[6] A fish with three rows of teeth is not to be despised.

Solution: [5- 2 - $6-3-1-4-6]$ All heavy fishes are kind to children.

The second is a literary piece by the same author, the well-known Through the LookingGlass, and What Alice Found There (1872), often ranged with the class of novels for children, or of fantasy novels.

The logical terms of the syllogisms are constructed as a set of creatures with bizarre features, evoking the natural context and then suspending it. The textual world in which these creatures function is of the same free and fluctuating nature as the world of the mirror, and their characteristics parallel those of the creatures Alice encounters while riding the train which runs "the wrong way" (Ch. III, p. 194), inside the looking-glass perimeter: the insect "making honey" and "bustling about among the flowers, poking its proboscis into them just as if it was a regular bee", but which is "in fact [...] an elephant" (p. 192), or the "very large Gnat" (mosquito) "about the size of a chicken" (p. 198), endowed with the gift of perfect designational logic.

32 Cf. also: [...] auch dieses Sich-einfach-auf-eine-empirische-Wirklichkeit-Beziehen, dieses Keinen-darüberhinausgehenden-fiktiven-Sinn-Haben, ist eine Art von Sinn" (Coseriu 1981: 49) 
Thus, although the two texts are different from the point of view of the textual traditions they belong to, in the sense of an integral typological model like the one envisaged here, they both manifest the same primary modality of sense construction, namely the poetic, and do in fact entertain numerous other intertextual connections at all levels of sense-articulation.

5.1.2. Another possible point of view is that of the most basic finalities of sense construction, which Coseriu assumes and develops in Aristotelian fashion, into the triad: "scientific" (or "apophantic") finality, associated with the values of truth vs. falseness, "pragmatic" finality, associated with the values of practical effectiveness and persuasiveness, and "poetic" finality, which is the maximal manifestation of the signifying potentialities of language itself. ${ }^{33}$

To take a poignant example, I will bring up the textual genre kōan, the insoluble paradox used in Zen Buddhism as a privileged technique for breaking the patterns of ordinary thought and consciousness, thus favouring the attainment of illumination. Below is a kōan and its accompanying commentary and "poem' ("verse") by Mumon Ekai, the $16^{\text {th }}$ case in the collection entitled Mumonkan (Gateless Gate, $1286^{34}$ ):

(4) The case [= kōan]

Unmon said, "The world is vast and wide like this. Why do we put on our seven-panel robe at the sound of the bell?"'

(Mumon's commentary):

[...] When you hear a sound, however, just tell me, does the sound come to the ear or the ear go to the sound? Even though you have extinguished both sound and silence, what will you realize here? If you hear with the ear, you cannot realize it. When you hear with the eye, for the first time it will become intimate.

(The verse):

With realization, all things are of one family,

Without realization, everything is separate and different;

Without realization, all things are of one family,

With realization, everything is separate and different.

Looking at the text of the kōan from the outside, so to speak, with a focus on its observable structures and overall composition, a Western reader will notice similarities with the style of some avant-garde literary texts ${ }^{35}$ and therefore feel tempted to consider it a manifestation of the "poetic" modality of sense-construction. However, in fact, the primary finality of a genuine kōan is always a practical (pragmatic) one. A kōan only makes sense in the framework of the immediate speech situation, where the locutor (Zen master) and the interlocutor (disciple) are both actually present, and in relation with the extra-verbal contexts, especially with what Coseriu calls the 'practical or occasional context'. ${ }^{36}$ The kōan aims to generate in the interlocutor a specific actional response: 'understanding' a kōan means to instantaneously operate an experiential mutation that transforms the whole structure of the disciple's personality, identity and selfawareness. At the level of primary discourse finality, a kōan instantiates in extreme form the function of "persuasion": one that requires the addressee (Zen disciple) not merely to modify some convictions or a course of action, but to operate a radical transformation of himself as a

\footnotetext{
See Coseriu 1948: 3 (footnote 2), 1957: 247, 1987c: 11.

English version by Master Kōun Yamada (1990).

The similarities are undeniable, but they pertain to textual constitution (expression) and reflect a secondary level of typological organization. An explanation will be proposed here in the section dedicated to the textual form of the second degree, along the lines of Mircea Borcilă's typological model (see infra, 5.2.). 
human being. 'Understanding' (solving) a kōan is not defined, in Zen, as a feat of 'cognition', 'thought' or 'interpretation', but as one of pure spontaneous action.

It might be added that, from the standpoint of the modality of sense-construction, at the level of $1^{\text {st }}$ degree form, a kōan manifests the prosaic modality of speaking "objectively" (sense construction with minimal leap, i.e. sense that tends to coincide with what the text signifies and designates), or, to borrow Coseriu's words, a "discourse that means exactly what it says and nothing more". 37

Even though the $1^{\text {st }}$ degree form does not seem to be identifiable in a straightforward way through formal markers of any kind, ${ }^{38}$ it expresses a typological intuition from which all interpretation begins, which sets the direction or orientation of interpretation and the values assigned to the text, and in the absence of which interpretation of the "real" text is, indeed, not possible.

5.2. More easily objectifiable seems to be a more determined level of form, textual form of the second degree, or what we might call 'sub-modes' / 'sub-modalities' of discourse. A fertile path of investigation at this level is offered by Mircea Borcilă's elaboration of the submodalities of the poetic modality, as "orientations" or "general intentions" of the process of discursive poesis, starting from the Romanian poet Lucian Blaga's dissociation of metaphors into "plasticizing (depicting)" and "revelatory" (Borcilă 1981, 1987, 1996, 1997a, 1997b). By applying two more "primary criteria" (the "existential-axiological principle" that governs the process of poesis and the "model of referential construction" in the text), Borcilă defines two major orientations of the process of constructing poetic sense:

(a) the "plasticizing (depicting)" finality: to enhance and 'revolutionize' perception and reconstruct the world in its salient details, heterogeneous, incompatible, according to an iconicdiagrammatic principle; the world thus created is mono-layered, since in it the essence is identical to the (perceived) manifestation;

(b) "revelatory" finality: to reveal an essence unseen behind appearances and indeed obscured by perceivable manifestations; the world thus created will be independent from the structure and laws of the empirical world, and phenomena will only serve to signal or symbolize the existence of a mysterious ontological plane of essences.

In turn, by the application of secondary criteria, each of these finalities are subdivided into two further subtypes, thus resulting in a total of four situations, illustrated by the work of several $20^{\text {th }}$ century Romanian poets. The model is summarized in the table below (Table 3). To avoid a lengthier explanation in the confines of this article, some English-language examples, given in the footnotes, will hopefully help the reader grasp intuitively the nature of the typological distinctions captured by Borcilă's model.

37 “[...] es gibt Texte, bei denen der Sinn mit Bedeutung und Bezeichnung zusammenfällt. Wird der Produzent eines solchen Textes gefragt, was er denn damit meine, so darf er unbekümmert antworten: 'Ich meine damit genau das, was ich sage'. Es gibt hier kein Gemeintes in Form eines autonomen Sinns, für den das Gesagte selbst nur Zeichenträger, signifiant wäre." (Coseriu 1981: 50)

38 It is also necessary to emphasize that the issue of the primary modalities of sense cannot fully be dealt with within the boundaries of text linguistics, but has to benefit from the perspectives and methods of other disciplines, in particular text poetics, as suggested above (5.1.1.) by reference to M. Borcilă's investigation into the nature of the poetic mode. 


\begin{tabular}{|c|c|c|c|}
\hline \multicolumn{3}{|c|}{ Sub-modalities of the poetic modality } \\
\hline \multicolumn{3}{|c|}{ "plasticizing" } & \multicolumn{2}{c|}{ "revelatory" } \\
\hline $\begin{array}{c}\text { "syntactic" } \\
\text { (A1) }\end{array}$ & $\begin{array}{c}39 \\
\text { "asemantic-asyntactic" } \\
\text { (A2) }\end{array}$ & $\begin{array}{c}40 \\
(\mathrm{~B} 1)^{41}\end{array}$ & $\begin{array}{c}\text { "semantic-syntactic" } \\
(\mathrm{B} 2)^{42}\end{array}$ \\
\hline $\begin{array}{c}\text { (coherence } \\
\text { preserved) } \\
\text { ex. Tudor Arghezi }\end{array}$ & $\begin{array}{c}\text { (coherence collapsed) } \\
\text { ex. avant-garde poetry }\end{array}$ & $\begin{array}{c}\text { (symbolic-mythic) } \\
\text { ex. Lucian Blaga }\end{array}$ & $\begin{array}{c}\text { (symbolic-mathematic) } \\
\text { ex. Ion Barbu }\end{array}$ \\
\hline
\end{tabular}

Table 3: M. Borcilă's subcategorization of poetic texts

For the non-poetic mode I am not aware of any theoretical elaboration that might correspond to the layer of $2^{\text {nd }}$ degree form. Nevertheless, the crucial point remains that the finality determines, subsumes and motivates the text's constitutional devices or strategies, and not the other way round. In this sense, Borcilă's model can certainly provide useful suggestions for a subtypology of non-poetic texts as well. In other words, in an integral typology the (sub)type cannot be confused with the thematic areas to which texts relate. Thus, the sub-modalities of the apophantic mode will not reflect as such the matrix of the various scientific disciplines with their object domains, and the sub-modalities of the pragmatic mode will not reflect the parameters of practical action or the social situations in which actions take place.

For example, I have argued elsewhere (2001: 133-139), that the kōan can be characterized, at the level of $2^{\text {nd }}$ degree form, by analogy with Borcilă's model, as a text of "plasticizing" orientation (meant to "revolutionize" perception), articulated according to a "asemanticasyntactic" principle, ${ }^{43}$ of constituting the text by a strategy of continual de-constitution. In the

39 A sum of enhanced disparate 'accidents' make up the very essence of manhood in Walt Whitman's I Sing the Body Electric: "The march of fire-men in their own costumes, the play of masculine muscle through cleansetting trousers and waist-straps, / The slow return from the fire, the pause when the bell strikes suddenly again, and the listening on the alert, / The natural, perfect, varied attitudes, the bent head, the curv'd neck and the counting; [...]".

40 The asemantic-asyntactic procedure of suspending cohesion and coherence can be recognized in E.E. Cumming's poem anyone lived in a pretty how town, where the rejection of traditional rules of combination allows for words to be freely endowed with totally new lexical and categorial valencies, as the following stanza illustrates: "all by all and deep by deep / and more by more they dream their sleep / noone and anyone earth by april / wish by spirit and if by yes."

41 Terms designating the empirical world are re-semanticized and replenished with mythical significance, thereby becoming windows to a mysterious space-time of unchanging essences in Langston Hughes's The Negro Speaks of Rivers: "I've known rivers: / I've known rivers ancient as the world and older than the flow of human blood in human veins. // My soul has grown deep like the rivers. // I bathed in the Euphrates when dawns were young. / I built my hut near the Congo and it lulled me to sleep. / I looked upon the Nile and raised the pyramids above it."

42 Subtype B2 is characterized in this model as 'symbolic-mathematic' based on the peculiar poetic technique used by Ion Barbu (mathematician Ban Barbilian) to conceive his poetry. I confine myself here to giving one striking example, from the poem Mod (Mode) with an English gloss meant to exhibit some of the synergic configurations of the original, without going into a detailed analysis: "O ceasuri verticale, frunţi tîrzii! / Cer simplu, timpul. Dimensiunea, două; / Iar sufletul impur, în calorii, / Şi ochiul, unghi şi lumea aceasta - nouă." (O vertical hours[/clocks], belated foreheads! / Simple sky, the time. The dimension, two; / And the impure soul, in calories, / And the eye, angle and this world -new [/ nine/ to us]). Illustrations of this subtype in English-language texts can be found, for example, in William Blake's work: "Tiger! Tiger! burning bright / In the forests of the night, / What immortal hand or eye / Could frame thy fearful symmetry? // In what distant deeps or skies / Burnt the fire of thine eyes? / On what wings dare he aspire? / What the hand dare seize the fire? [...]" (The Tiger)

43 See Borcilă 1981:31-32, 1987:188, 190, 192. Since avant-garde poetry manifests this principle in a striking way, the constitutional similitude mentioned before (5.1.2.) does not come as a surprise. 
end, 'solving' a kōan (i.e. realizing its sense) marks its dissolution as a text and fusion with the world as such, or - which in Zen is the same - with the experience of the world as such.

5.3. The textual form of the third degree is the level for which I would like to reserve the term 'text type' in a restricted acceptation, designating the homogeneous principles that govern the sense-construction process in each "real" text: a far-reaching unity that explains coherently all the different constitutional units, procedures and strategies at work in each individual text. Text type in this understanding is never given beforehand, but must be hermeneutically discovered in each text. It is necessary to emphasize, however, that in the perspective of integral text linguistics, a "real" text is to be considered:

(i) with its actual constitution (the particular configuration of units, textual functions, evocative functions, general textual procedures and their means of realization);

(ii) as a whole, up to the maximal identifiable limit of the process of sense-articulation, which can sometime unfold beyond the material borders of the individual text, towards a higher unit such as the whole creative activity of an author, traditionally called the Oeuvre (Coseriu 1981: 123). ${ }^{44}$

Sometimes, the process of sense-articulation has to be followed beyond the limits of one author's work, in rare cases where unseverable constitutional ties unite one author's text with another author's text. I do not have in mind here local intertextual references that evoke units or devices from another author's work, or situations of 'engulfment' (subordination, in the main body of a text, of certain segments of another text), but rather the cases of genuine dynamic integration of two texts at all constitutive layers. I have identified one such instance in the Romanian version of Shakespeare's Richard III created by the Romanian poet Ion Barbu, where the process of sense-articulation must be interpreted all the way up to the scale of the superior unit it forms together with the original English text. Discovering the authentic text type of Barbu's Richard III will depend entirely on the success of this undertaking. Even though, at first sight, the translation bears little surface resemblance to the original, but, rather, echoes the voice of Barbu's own original hermetic poetry, ${ }^{45}$ a careful analysis will reveal that the two texts are inextricably linked, as Barbu programatically undertook to translate not the original as a finished product, but to revive, with the means of the Romanian language, the very process which led to the construction of the original. For this purpose, the original is first broken down into constituent units and procedures, held together only by the gravitational force of the interpreted sense, and then re-constituted with the expressive means of Romanian, in the asymptotic direction of this sense. ${ }^{46}$

44 It goes without saying that I do not imply the reverse: the work of one and the same author does not necessarily constitute a unitary macro-text in this sense. From the perspective of a text-linguistic approach, one must treat the identity of the real author as a mere accident, which does not entail coherence from a typological point of view.

45 To back up this statement, let us take, for purposes of illustration, the first lines from Clarence's account of his premonitory dream (I:iv, 9-13): "Methoughts that I had broken from the Tower, / And was embark'd to cross to Burgundy; / And in my company my brother Gloucester, / Who from my cabin tempted me to walk / Upon the hatches: thence we look'd toward England". In Ion Barbu's version, these lines read: "Pluteam în larg, în cercul mult al undei, / Din turn scăpat, tăind către Burgundii, / Cu Gloster printre funii, căngi, catran. / De-acolo el mă ridică pe punte, / Cu faţa către-o Anglie de var". [Gloss: Afloat was I [/ we were] in the open, in the plenteous circle of the wave / From the tower escaped, cutting towards Burgundies / With Gloucester amongst ropes, harpoons, tar. / Therefrom he lifted me onto the bridge / To face a whitewashed England]. For comparison, here is Dan Duţescu's orthodox translation: "Părea că-s mîntuit, fugit din Turn, / Și spre Burgundia pluteam pe-o navă: / De soţ l-aveam pe Gloucester, al meu frate, / Ce m-a-mbiat pe punţi să ne plimbăm: / Deacolo ne uitam spre Englitera".

46 For a detailed analysis, see Tămâianu 1994 and 2001: 144-167. 
Difficult though it is to exemplify the $3^{\text {rd }}$ degree form in a concise way, given the fact that it only results from the comprehensive analysis of a text in its integrality, I will refer here once again to the case of Lewis Carroll's Through the Looking-Glass, and What Alice Found There. By interpreting this text in its «reality» and «integrality», ${ }^{47}$ i.e. taking into account all of its constitutive characteristics and all the evocative relations that link it to Alice in Wonderland and the Sorites, ${ }^{48}$ a global formative principle can be identified:

\section{General typological principle:}

The text is constructed compositionally as a game of chess, and semantically as a syllogism, more precisely as a «dream» with syllogistic expression.

\section{Typological norms that manifest this principle:}

(a) In its constitutional side, the text it not ready-made, nor is it given to the reader already constructed beforehand, but presents itself as an unstructured raw material, out of which the building of a text is required: the constitutional units are the data of a problem that needs to be solved. ${ }^{49}$

(b) Constitutional elements selected from the culturally-marked domain of fictional literature and myth (the Unicorn, the nursery rhyme characters etc.) are systematically deconstructed and put to act in an alternative fiction, in complete disjunction with the textual tradition from which they were taken up. They thus become symbols (in the logical or mathematical sense) in a demonstration of the mind's freedom to make up ideal objects, for which an empirical correlatum or a cultural connotation do not exist or are treated as irrelevant.

(c) Unaffected by judgements of truth/falseness and possibility/impossibility, the dream sets up and self-attests its world via a process of valid reasoning, unfolded with strict observance of the rules of the Mirror. ${ }^{50}$

\section{The proposed definition of text type and some necessary conceptual distinctions}

6.1. By analogy with Coseriu's definition of language type proper, I have defined text type as: the functional level which explains the orientation and unfolding of sense-construction, the layer of the categories of functions and devices for text constitution, where the homogeneity and functional coherence underlying the diversity of the functions and devices as such can be revealed.

47 This analysis is proposed in Tămâianu 2001: 102-111.

48 Particularly important is Sorites 47, of a meta-logical nature, which deals with the relationship between «dreams», «syllogisms» and «truth» and yields, as one intermediary conclusion, the proposition "My dreams can be expressed as Syllogisms".

49 The Sorites are introduced by the instruction: "Sets of concrete propositions, proposed as premisses for sorites. Conclusions to be found." Similarly, after the prologue and list of dramatis personae, Through the Looking-Glass begins with a chess-problem: "White Pawn (Alice) to play, and win in eleven moves". In the final chapter the problem is reformulated as "Which dreamed it?" (Alice or the Red King). The initial formulation pertains to the constitution of the text: we are asked to correctly place in their mutual relation the various segments and components of the text so that Alice=the white pawn should win in 11 moves. The final reformulation regards the sense of the text: we are required to coherently articulate the various sense units of the game, which is a a game of dreaming.

50 These are rules of inversion ("living backwards", Ch. 5, p. 225), manifested both in the topology and in the dynamics of the Looking-Glass world: going "forward" leads "backwards", the "valleys" are "hills", in order to stay still you have to run as fast as possible (Ch. II), the effect precedes the cause (Ch. V, VII), memory is 
The immediate consequence of this understanding is that text type in an integral typology cannot be an abstract pattern defined through a finite set of parameters (and not even through an 'open' set of parameters), because such a pattern is nothing more than a mere construct that records, by selection and addition, features manifested in textual products. Such composite patterns do not exist as such in the intuitive (technical) knowledge of speakers, but pertain to a certain type of epistemic exploration and description of individual speech. While perfectly justified as epistemic instruments, it is illegitimate to project these constructs 'retroactively', so to speak, into the speakers' competence. It is this act that generates the false problem of the 'deviations' from the 'type' (as all real texts will necessarily be 'deviations' from such constructs), with its cohort of unanswerable questions regarding the 'degree of tolerance' within which 'deviations' can occur without affecting the 'type'.

However, descriptions (not "definitions"!) ${ }^{51}$ through sets of parameters or matrix-like structures of characteristics are possible and justified for the 'external' species of texts, literary genres included. These genres are not text types in the definition proposed above ('form' of discourse), but textual traditions historically constituted on the basis of exemplary models. Such are, from Coseriu's examples (1982: 164), "the sonnet" and "the fairy-tale" - models that reflect classifications from the viewpoint of discourse as product (ergon) in Coseriu's triadic model (see Table 2). Other obvious illustrations are the various texts with fixed compositional formulas from the juridical or administrative domains, as well as genres found in daily factual communication (narratives of personal experience, instructions for getting to a certain location, cooking recipes etc.). Needless to say, any procedure and any text can become the starting point of a tradition. Nothing prevents the appearance of a whole new genre based on the model of Lewis Carroll's Through the Looking-Glass, namely a syllogism-text.

To give a further example, coupled with a necessary warning: from this point of view, it is obvious that Whitman's poem So Long! can be included in a genre (tradition) of «texts that begin with the conclusion», based on the identification of the corresponding (constitutional) device or strategy for initiating a text. Useful as this perspective is, we have to point out that it also has inherent limitations: it does not allow us to go any further, to carry the typological characterization towards the level of sense, since the sense is given by the function fulfilled by the procedure in this individual text, a function which can only be found by full interpretation in relation to other elements of this text in its integrality.

6.2. We have thus reached a first distinction that I consider essential in the area of an integral text typology, namely the distinction between text type proper and text species / genre (or textual tradition). Similar to historical languages, textual traditions are individuals, not general or universal entities, ${ }^{52}$ so the issue cannot be that of 'defining' them in a 'theory' of genres, but that of describing their structure and evolution, in a history of textual species (cf. Coseriu 1971/1977: 205). Their historical-individual nature entails several immediate consequences:

(a) There are neither rational limits among genres, nor a predetermined number of 'possible' genres. ${ }^{53}$

inclusive of the future (Ch. V), language is pure denotation etc.

51 Cf. infra, 6.2 .

52 Kabatek (2005a) proposes an in-depth analysis of the issue of the historicity of texts; especially relevant for the idea underlined in this section is his discussion of the "second type of historicity", which characterizes textual traditions, and his arguments for the necessity of distinguishing between the "primary" historicity of language itself and the "secondary" historicity of textual traditons (pp. 152-154).

53 Oscar Loureda (2003: 41-42) holds the same position on this point in his typological proposal. 
(b) If it is true that genres are identifiable on the basis of privileged exemplary models, it is equally true that - given the fundamentally creative nature of all discourse - change (creative modification) ${ }^{54}$ is engraved in their very nature of discourse models. In this sense, the model of a textual genre represents only an abstract frozen frame ${ }^{55}$ in a dynamic reality.

(c) Positive lists of 'necessary and sufficient' features for a text to belong to a certain textual tradition cannot be drawn up. In other words, the 'degree of tolerance' for the shift from the exemplary model cannot be quantified, and a 'threshold value' beyond which one text 'passes', so to speak, into a different species cannot be predicted by way of principle. ${ }^{56}$ From the perspective of integral text linguistics the issue should be formulated, I believe, in reverse terms: for each individual text, one can recognize the innovation as compared to other texts with which the given text entertains special evocative relations, including the innovation as compared to those texts which are elevated by tradition to the status of exemplary models for a certain genre.

6.3. To clarify the next typological distinction, I will again refer to the analogy between Coseriu's typology of languages and the typology of texts (supra, 3.).

In the field of texts, one kind of grouping most commonly and easily effected is that of text categories (Textsorten), such as the category 'newspaper article' understood as an array of devices for journalistic texts. Understanding text categories as arrays of devices is also backed up by the example of the ellipsis in the "Telegrammstil", which is subordinated to the term Textsorte in Coseriu 1981 (p. 21). Such categories of texts are obtained by "die Erfassung und Einordnung der unendlichen Vielfalt konkreter Texte aufgrund von Merkmalen, die mehreren, u.U. sehr vielen Texten gemeinsam sind" (Coseriu 1981: 117; italics mine - E.T.-M.).

If I am not mistaken in my judgment based on Coseriu's examples, in the absence of an explicit definition, the term Textform (e.g.: greeting, indirect narrative) should be logically subordinated to the term Textsorte, and interpreted precisely as designating textual devices or procedures, considered not from the standpoint of their elocutional function or their idiomatic realization, but from the standpoint of their contribution to the constitution of sense.

The nature of text categories (Textsorten) will appear more clearly if considered from the angle of the analogy with the typology of languages, where they would correspond to the "global" morpho-syntactic types, while the Textformen would be analogous to the partial morpho-syntactic types, as results from the following statement, formulated by Coseriu with the purpose of clarifying the limitations of traditional language typologies, and therefore with the terms (language - text) inverted:

Sprachtypen wie der 'isolierende', der 'agglutinierende' oder der 'flektierende' Typ [...] verhalten sich zu den Einzelsprachen wie die 'Textsorten' zu den konkreten Texten. Sie glieden die Vielfalt der historisch überlieferten 'Techniken des Sprechens', ohne jedoch eine einzige von ihnen so erschöpfend zu charakterisieren, wie etwa die Definition des 'gleichseitigen Dreiecks' die unter sie fallenden Gegenstände charakterisiert. (Coseriu 1981: 117; italics mine - E.T.-M.)

Just as the partial or the global morpho-syntactic typologies do not represent typologies of "real" languages, the categories of texts should not be confused with what I hold to be "text

54 The issue of the mechanisms of linguistic change and of their consequences for understanding the structuring of particular languages (the historical level in Coseriu's triad) is amply discussed in Coseriu 1958/1978 and 1983b.

55 To be sure, its value for methodological purposes is not questioned here.

56 Kabatek (2005b: 161) rightly points out that, by virtue of their "paradigmatic compositionality" (one text can be subsumed simultaneously to diverse discourse traditions), discourse traditions can change over time, "y pueden cambiar totalmente hasta convertirse en otra realidad totalmente diferente de la inicial". 
type' proper. The usefulness of describing Textsorten and the justification for using them in the search for the actual text type derive from the fact that text categories offer a first ordering in the countless variety of concrete texts, and, as far as they themselves are the expression of a text-typological intuition, provide guidance for discovering the type of "real" texts.

Usefulness ends, however, where confusion begins. Mistaking these categories for text type proper will generate, in the domain of text typology, the same insoluble paradoxes, the same deadlocks and interpretive errors as the ones faced by the morpho-syntactic typologies of languages.

Text categories appear in the synchronic investigation of texts. On the other hand, a diachronic perspective reveals the development of textual genres (Gattungen), analogous to the families of languages: these can be said to represent 'genealogical' groupings based on an initial common model, never exactly reproduced, nor merely imitated. ${ }^{57}$

In the attempt to systematically explain the construction of sense (i.e. to identify and describe the general procedures of sense construction), an integral text typology will include among its aims the investigation of text categories and genres (cf. Coseriu 1981: 152), without, however, restricting its focus to them.

6.4. A final distinction concerns characterizations of texts through labels like 'monologue' / 'dialogue', the so-called 'narrative styles' (direct, indirect, free indirect speech etc.), and even the classical triad 'lyric' / 'epic' / 'dramatic' (as far as it is based on configurations concerning the relationship 'speaker' - 'hearer'). Here, recourse is made to a set of parameters corresponding to what Coseriu terms "the general determinations of individual speech", namely "a. the speaker; b. the interlocutor; c. the object [that is being spoken about]; $d$. the situation [of speech]" (Coseriu 1988: 160-161). Communicative-actional theories of textuality attempt precisely to identify parameters pertaining to such determinations, equating them to text-typological dimensions. From the perspective of an integral typology, the variants (possible realizations) of these four instances justify not text types, but something we might call modalities of speech in general, or elocutional modalities.

Strictly speaking, the elocutional modalities are not pan-idiomatic (i.e. something found, by descriptive investigation, to be common to 'all' historical languages), but pre-idiomatic, i.e. logically prior to the specific idiomatic structuring (a common foundation situated at the universal level of language in general). Nevertheless, as is the case with any elocutional norms, their realization can be limited through the means of expression peculiar to each language. ${ }^{58}$

Moreover, these modalities are also pre-textual. At the individual level of speech, the textual level proper, elocutional modalities become part of the textual constitution, i.e. part of the textual signifier, and therefore should not be confused with discourse modes as basic orientations or finalities of sense-construction.

\section{The proposed definition of text type and some methodological consequences}

Defining 'text type' as a formative layer of the text itself has several implications concerning the manner in which a text type can be discovered and described.

57 See Coseriu 1981: 118. This statement should be interpreted in connection with observations (b) and (c) from section 6.2 .

58 For example, in a language like Japanese, where all predicates are impersonal, so that events and states can be and often are presented without any specific relation to an agent or experiencer, a 'free indirect style' of speech is very difficult to attest as such, though it remains a theoretical possibility. 
(1) A text type cannot be empirically recognized in a direct way, by the presence/absence or statistics of units, devices, structures, or even textual functions as such, but must be discovered through the hermeneutic investigation of these elements, as parts of the textual constitution, all the way up to the principles that explain in a unitary manner their role in the process of sense-construction.

(2) A text type is not a class of texts grouped according to certain common features (units, structures, devices). Also, a text type is not a paradigmatics of text-constitutional units and devices. Unlike text genres, which can be recognized on the basis of exemplary models, texttypological principles in my definition represent a structuring layer of the text itself, taken in its individuality; it then makes no sense to discuss the issue of 'deviations from the type'. In other words, the main obstacle which faces the orientations that propose a taxonomical definition of text types - namely the issue of the 'degree of tolerance' or 'threshold values' - is resolved by adopting the definition and distinctions advocated here, i.e. by shifting the focus from ideal classes or composite models to the typicalness of the individual texts themselves.

(3) The integral typology of "real" texts cannot be a typological matrix. A deductive (and predictive) table of 'all' text types cannot be built, as a matter of principle. It is beyond doubt that, in the field of textuality, just as in the field of languages, the search for a deductive matrix aspiring to completeness exerts unending fascination. Once the 'types' (axes or parameters of structuring methods) have been established, there would be nothing else left to do than to 'apply' them to genuine texts. No matter how attractive, however, such an enterprise can neither avoid, nor solve the paradox of the 'gradual' typicalness or 'non-typicalness' of individual texts.

(4) It is a fact that, in a general perspective, textual typology concerns itself with establishing typological possibilities of texts. The term "typological possibilities" does not mean, however, abstract strands of functions or properties, or logically possible connections thereof, since these exist in theoretically infinite numbers, just as, I should perhaps stress, the typological 'impossibilities' of texts also exist in theoretically infinite numbers. Typological research in the framework of integral text linguistics should aim at identifying "real" types in the same way as the functional investigation of languages does not envisage 'all' possibilities of idiomatic structuring, but only "«real» linguistic possibilities" ("reale" sprachliche Möglichkeiten): ${ }^{59}$ those expressive possibilities that are discovered as realized in real languages / texts or derive from such possibilities.

From this point of view, every text type or text-typological principle identified in a text constitutes a possible universal, ${ }^{60}$ and qualitative multitude is perhaps even more obvious here than in the area of the possible universals of language in general or of particular languages, owing to the loose nature of textual norms and adequacy evaluations. For the discovery of text types in our definition, the quantitative extension of corpora is therefore of no direct relevance in and by itself. What is pertinent, instead, is the qualitative aspect of the functional "plenitude" 61 and diversity of the texts chosen as objects for analysis.

60 The three main types of objective universals are: essential, possible and empirical (empirical generality) (Coseriu 1970a: 208, 1970b: 110-111, 1973/1981: 37-39, 1974: 149-165).

61 As defined in Coseriu 1971/1977: 201-203, 1981: 109-111, 1987a: 24-25. 


\section{Synopsis and final remarks}

8.1. Taking into account the points made in the previous sections, a synopsis of the conceptual distinctions I consider crucial in an integral text typology is presented in the Appendix.

In this paper, my primary focus of interest has been the third level in Coseriu's triad presented in Table 2, namely the individual level of discourse as a process of senseconstruction. At this level, the term "text type" could be used in a broad sense to cover textual form of the $2^{\text {nd }}$ and $3^{\text {rd }}$ degrees (as indeed it is sometimes used even for $1^{\text {st }}$ degree form). For the sake of clarity, and in keeping with the view of a typology of "real" texts, I would rather plead in favour of using the term "type" in a restricted sense, only for $3^{\text {rd }}$ degree form, since this is the layer where the typological coherence of the individual text can be attested and explained, and the terms "modes" ("modalities") and "sub-modes" ("sub-modalities") for the other levels.

The vantage point from which the typological notions pertaining to the textual level are defined is indicated in the synoptic table as "functional" motivation (for the layers of textual form in the individual text) vs. "historical" motivation (for text categories and text genres). These angles are to be understood according to Coseriu's thesis (1988: 221-222) that the speaker's competence as a technical knowledge at every level - therefore, consequently, also text-typological knowledge as part of expressive competence - can have two types of "immediate objective motivation":

(1) the "historical motivation": justification by recourse to the (re)cognition of fashions of speaking given in the tradition of linguistic communities;

(2) the "functional motivation": justification by the fact that a different way of expression would bring about a different meaning.

These two perspectives are meant to clarify the relations between the different notions that conceptualise the typicalness of "real" texts, and should not be confused with the levels of speech in Coseriu's basic triad of the universal, the historical and the individual.

8.2. I have also pointed out that notions such as 'monologue' / 'dialogue' or the so-called 'narrative styles' (direct, indirect, free indirect speech etc.), as far as they are defined through parameters that correspond to what Coseriu terms "the general determinations of individual speech", represent modalities of speech in general (elocutional modalities), and should be properly situated not at Level III (textual), but at Level I (speaking in general) in Coseriu's triad. The respective notions are therefore indicated in the Appendix with reference to Level I.

I have not dealt here with the issue of idiomatic units, devices and rules correlated with or specialised for text-constitutive functions. ${ }^{62}$ Consequently, Level II (the level of idiomatic organization) does not appear in the Appendix. It is entirely conceivable, however, that such elements may also present typological relevance for the characterization of «real» texts, as an integral part of their constitution. From this perspective, these idiomatic devices deserve a separate discussion, to be undertaken in the course of further investigations.

8.3. Needless to say, the task of developing a proper conceptual framework and descriptive methods for the $1^{\text {st }}$ degree form (the fundamental orientations of sense construction) and the $3^{\text {rd }}$ degree form remains daunting, especially since both presuppose the prior establishment of a coherent framework for the description of text-constitutive units and their correlation with sense-units. ${ }^{63}$ The difficulty is compounded by the fact that patchwork (partial or local)

62 Such phenomena are discussed, for instance, in Coseriu 1981: 12-22 and 154-176, 1988:168-169 and 171-172, 1979b: 41-43.

63 Some suggestions are offered in Tămâianu-Morita 2009 and 2012. 
solutions do not seem to work, since the ambition of the «integral» paradigm put forward by Eugenio Coseriu is to open up the path to a radical reconstruction ${ }^{64}$ of the whole field of text linguistics (textual typology included), providing a unitary framework where valid intuitions and descriptions from models of different theoretical orientations can be properly placed, revalued and systematically developed.

64 The coordinates of what can rightly be called an "integralist revolution" in the field of linguistics and humane sciences in general are amply debated by Mircea Borcilă (1988, 1991, 1996, 2001a, 2001b, 2002). 
Appendix: Synopsis of text-typological distinctions in an «integral typology of real texts»

I. UNIVERSAL LEVEL (SPEAKING IN GENERAL):

Elocutional modalities

Ex. dialogue/monologue, direct/indirect/.../ speech)

III. INDIVIDUAL LEVEL (DISCOURSE / TEXT):

Functional motivation

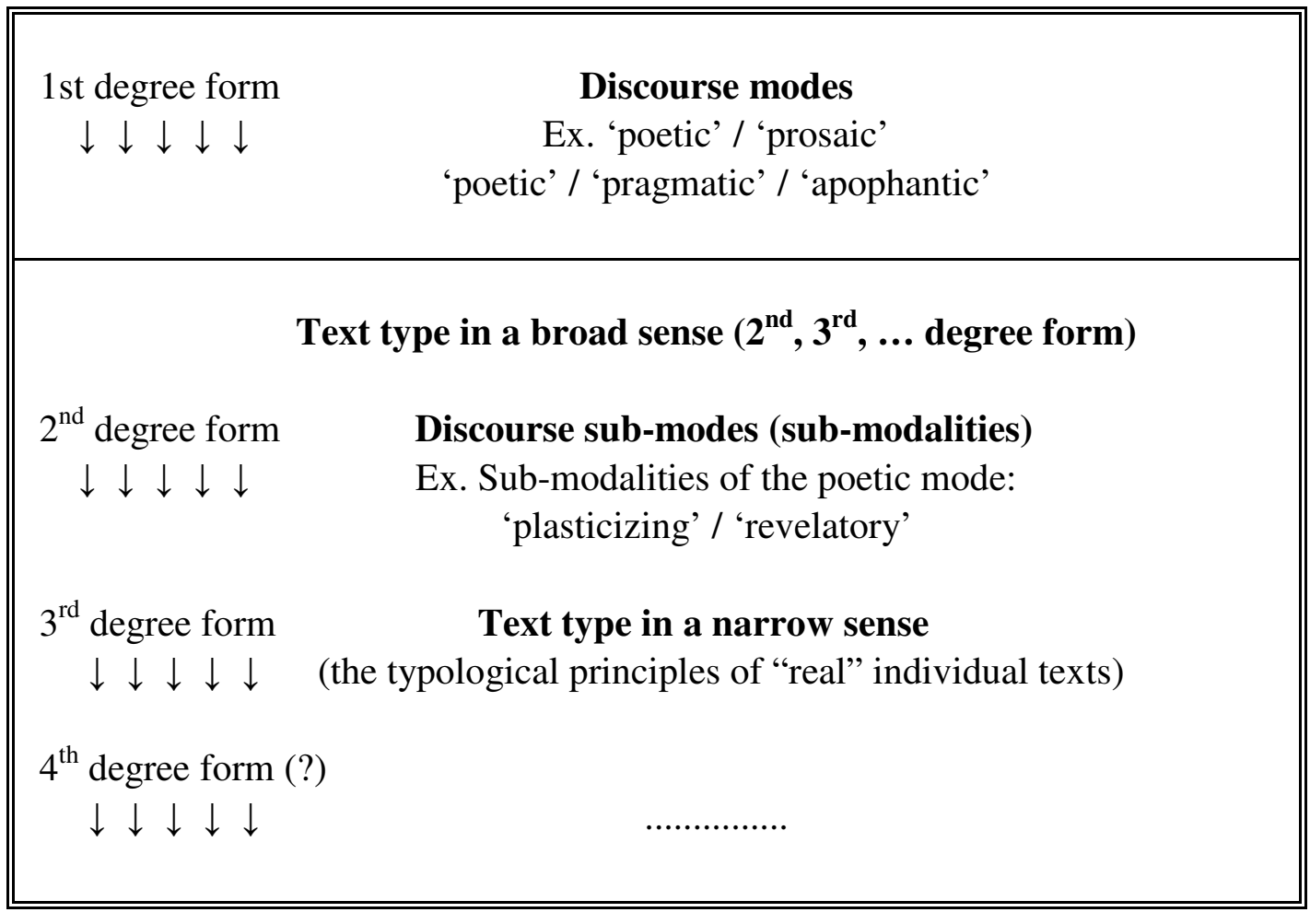

Historical motivation

Synchronic perspective

Diachronic perspective

Categories of texts,

Text genres,

methods of text-construction

textual traditions 


\section{Bibliography}

Borcilă, Mircea (1981): “Types sémiotiques dans la poésie roumaine moderne”, in: Miclău, P. / Marcus, S. (eds.): Sémiotique roumaine, Bucureşti: Universitatea Bucureşti, 19-35.

- (1987): "Contribuţii la elaborarea unei tipologii a textelor poetice", in: Studii și cercetări lingvistice, XXXVIII, 3, 185-196.

- (1988): "Eugenio Coseriu şi orizonturile lingvisticii”, in: Echinox, XX, no. 5, pp. 1, 4-5.

- (1991): "Eugenio Coseriu and the Development of Linguistics", in: Studia Universitatis Babeş-Bolyai, XXXVI, no. 3-4, 3-9.

- (1996): "Bazele metaforicii în gîndirea lui Lucian Blaga", in: Limbă şi literatură, XLI, 1, 28-39.

- (1997a): "Între Blaga şi Coşeriu. De la metaforica limbajului la o poetică a culturii”, in: Revista de filosofie, XLIV, no.1-2, 147-163.

- (1997b): "The Metaphoric Model in Poetic Texts", in: Szöveg és stílus. Szabó Zoltan köszöntése, Cluj-Napoca: Babes-Bolyai University, 97-104.

- (2001a): "Eugeniu Coşeriu şi bazele ştiinţelor culturii”, in: Academica, XI, 7-8 (127-128), May - June 2001, 22-23.

- (2001b): “Început de drum în studiile integraliste”, in: Studia Universitatis Babeş-Bolyai, XLVI, 4, 3-14.

- (2002): "Eugeniu Coşeriu, fondator al lingvisticii ca ştiinţă a culturii", in: Un lingvist pentru secolul XXI. Materiale ale Colocviului Internaţional "Filologia secolului XXI" organizat cu prilejul a 80 de ani din ziua naşterii Prof. Eugeniu Coşeriu (Bălţi, 18-19 mai 2001), Chişinău: Ştiinţa, 31-39.

Coseriu, Eugenio (1948): "La lingua di Ion Barbu (con alcune considerazioni sulla semantica delle lingue 'imparate"”, in: Atti del Sodalizio Glottologico Milanese, I, Dec. 1948, 3-8.

- (1955-56): "Determinación y entorno. Dos problemas de una lingüistica del hablar", in: Coseriu 1962, 282-323.

- (1957): "Logicismo y antilogicismo en la gramática", in: Coseriu 1962, 235-260.

- (1958/1978): Eugenio Coseriu, Sincronía, diacronía e historia. El problema del cambio lingüístico, Montevideo; Romanian translation (after the $3^{\text {rd }}$ revised edition, Madrid, 1978) by N. Saramandu: Sincronie, diacronie şi istorie. Problema schimbării lingvistice, Bucureşti: Editura Enciclopedică, 1997.

- (1962): Teoria del lenguaje y lingüistica general. Cinco estudios. Madrid: Gredos.

- (1968): "Sincronía, diacronía y tipología", in: Coseriu 1977b, 186-200.

- (1969): "Semántica, forma interior del lenguaje y estructura profunda", in: Coseriu 1978, 112-127.

— (1970a): "Significado y designación a la luz de la semántica estructural”, in: Coseriu 1977a, 185-209.

- (1970b): “Alcances y límites de la gramática contrastiva”, in: Coseriu 1978, 80-111.

- (1971/1977): “Tesis sobre el tema 'lenguaje y poesía”, in: Coseriu 1977b, 201-207.

- (1973/1981): Lezioni di linguistica generale, Torino, 1973; revised Spanish version: Lecciones de lingüística general, Madrid, 1981; Romanian translation by E. Bojoga: Lecţii de lingvistică generală, Chişinău: Arc, 2000.

- (1974): "Los universales del lenguaje (y los otros)", in: Coseriu 1978, 148-205.

- (1977a): Principios de semántica estructural. Madrid: Gredos.

- (1977b): El hombre y su lenguaje. Estudios de teoría y metodología lingüística. Madrid: Gredos. 
- (1978): Gramática, semántica, universales. Estudios de lingüística funcional. Madrid: Gredos.

- (1979a): "Humboldt und die moderne Sprachwissenschaft", in: Energeia und Ergon, I, Tübingen, 1988, 3-11.

- (1979b): "Verbinhalt, Aktanten, Diathese. Zur japanischen Ukemi-Bildung", in: Ezawa, K. \& Rennsch, K.H. (eds.): Sprache und Sprechen. Festschrift für Eberhard Zwirner zum 80. Geburstag. Tübingen: Niemeyer, 35-55.

- (1981): Textlinguistik. Eine Einführung. Tübingen: Narr. Critical Spanish edition (2007) by Óscar Loureda Lamas, Lingüística del texto. Introducción a la hermenéutica del sentido. Madrid: Arco Libros.

- (1983a): "Sprachtypologie und Typologie von sprachlichen Verfahren", in: Allgemeine Sprachwissenschaft, Sprachtypologie und Textlinguistik (Festschrift für Peter Hartman). Tübingen: Narr, 269-279.

- (1983b): "Linguistic Change Does Not Exist", in: Linguistica nuova ed antica, Anno I, Galatina, pp. 51-63; Romanian Translation by E. Tămâianu: Nu există schimbare lingvistică, in: Cercetări de lingvistică, XXXVII, 1992, 1, 9-20.

- (1987a): "Acerca del sentido de la enseñanza de la lengua y literatura", in: Innovación en la enseñanza de la lengua y la literatura, Madrid, 13-32.

- (1987b): "Überblick über die Ergebnisse der Plenarsitzung 'Typologie: ganzheitliche Typologie versus Teiltypologie",, in: Proceedings of the Fourteenth International Congress of Linguists, Berlin 1987, vol. I/2, Berlin: Akademie Verlag, 1991, 237-242.

- (1987c): "Lenguaje y política", in: Alvar, M. (ed.): El lenguaje politico. Madrid, 9-31.

- (1987d): "Le latin vulgaire et le type linguistique roman", in: Latin vulgaire - latin tardif. Actes du Ier Colloque international sur le latin vulgaire et tardif (Pécs, 2-5 sept. 1985), Tübingen, 53-64.

- (1987e): "Die Ausdruckslücke als Ausdrucksverfahren (Textlinguistische Übung zu einem Gedicht von Kavafis)", in: Stuttgarter Arbeiten zur Germanistik, 189, "Sinnlichkeit in Bild und Klang”. Festschrift für P. Hoffman zum 70. Geburstag, 373-383.

- (1988): Sprachkompetenz. Grundzüge der Theorie des Sprechens. Tübingen: Francke.

- (1989): "Principes de syntaxe fonctionnelle", in: Travaux de linguistique et de philologie, XXVII, Strasbourg-Nancy, 5-46.

Humboldt, Wilhelm von (1836/1988): Über die Verschiedenheit des menschlichen Sprachbaues und ihren Einfluß auf die geistige Entwicklung des Menschengeschlechts; English translation: On Language. The Diversity of Human-Language Structure and Its Influence on the Mental Development of Mankind. Cambridge: Cambridge University Press.

Kabatek, Johannes (2005a): “À propos de l'historicité des textes”, in: Murguía, A. (ed.): Sense et Références. Mélanges Georges Kleiber. Tübingen: Narr, 149-157.

- (2005b): "Tradiciones discursivas y cambio lingüístico", in: Lexis, 29/2, 151-177.

Kabatek, Johannes / Murguía, Adolfo (1997): “Die Sachen sagen, wie sie sind...”. Eugenio Coseriu im Gespräch. Tübingen: Narr.

Loureda Lamas, Óscar (2002): "Los tipos de texto", in: Romero, V. (ed.): Lengua española y Comunicación. Barcelona: Ariel, 155-176.

- (2003): Introducción a la tipología textual. Madrid: Arco Libros.

- (2006): "La lingüística del texto de Eugenio Coseriu: las dimensiones reales y funcionales de los discursos", in: Coseriu, Eugenio / Loureda, Óscar: El lenguaje y el discurso. Pamplona: EUNSA. 
Tămâianu, Emma (1994): “A Contrastive Analysis of Clarence's Dream (Ion Barbu's Translation of Richard III)", in: Proceedings of The First National Conference of the Romanian Society for British and American Studies. Cluj-Napoca: Babes-Boyai University, 282-294.

- (2001): Fundamentele tipologiei textuale. O abordare în lumina lingvisticii integrale. Cluj-Napoca: Clusium.

Tămâianu-Morita, Emma (2002): Integralismul în lingvistica japoneză. Dimensiuni - impact perspective. Cluj-Napoca: Clusium.

- (2005): "Semantic Revival of a Cliché in Shakespeare's Plays: 'All Is Well'”, in: Studia Universitatis Babeş-Bolyai, Philologia, L, 2005, 1, 163-185.

- (2006a): "Is Poetic Text 'Homologous' to 'Language?' A Romanian - Japanese Case Study", in: Studia Universitatis Babeş-Bolyai, Philologia, LI, 1, 57-85.

- (2006b): "Înspre un model textual-tipologic integralist", in: Revista de lingvistică şi ştiinţă literară (Chişinău), 2006, no. 1-2, 52-59,

- (2006c): "Cîteva distincţii conceptuale de bază într-o tipologie textuală de orientare integralistă”, in: Limba Română (Chişinău), XVI, no. 4-6, 14-29.

- (2007): "Strategies of Sense-Construction in a Transidiomatic Text. A Linguistic Perspective", in: Manolache, Simona-Aida / Măciucă, Gina (eds.): Inter Litteras et Terras (I). Proceedings of the International Conference on Comparative Literature, Contrastive Linguistics, Translation and Cross-Cultural Studies (September 21-23, 2007). Suceava: Editura Universitatea "Ştefan cel Mare", 312-321.

- (2009): “On the Concept of 'Textkonstitution"”, in: Eugenio Coseriu's Text Linguistics, Paper presented at the Second International Congress of Integral Linguistics, Coseriu Contemporary Perspectives, Cluj-Napoca, 23-25 September 2009.

- (2012): "Rethinking Coseriu's Notion of 'Unit of Textual Meaning' (Sinneinheit)", in: Analecta Malacitana, special issue "Eugenio Coseriu (1921-2002) en los comienzos del siglo $X X I », 86 /$ II, 75-94 (in print). Based on a paper presented at The Third International Congress of Integral Linguistics, «Eugenio Coseriu, lingüista entre dos siglos», Almeria, Spain, 5-7 October 2011.

\section{Analysed Texts}

Carroll, Lewis (1952): “Through the Looking-Glass, And What Alice Found There (1872)", in: Alice's Adventures in Wonderland and Through the Looking-Glass. London \& Glasgow: Collins Library of Classics, 155-318.

Carroll, Lewis (1970): "Sets of Concrete Propositions, proposed as Premisses for Sorites (1896)", in: The Complete Works of Lewis Carroll, New York: Random House. 1242-1265.

Shakespeare, William (1964): Viaţa şi moartea regelui Richard al III-lea. Echivalenţe româneşti de Ion Barbu, ed. by Romulus Vulpescu, Bucureşti: Editura pentru literatură.

Shakespeare, William (1986): A Midsummer Night's Dream (The Arden Shakespeare) ed. by Harold F. Brooks, London and New York: Methuen.

Shakespeare, William (1987): King Richard III (The Arden Shakespeare), ed. by Antony Hammond, London and New York: Methuen; Romanian translation by Dan Duţescu: Richard al III-lea, in: Leviţchi, Leon (ed.): Opere complete, vol. I, Bucureşti: Univers, 1982, 475-582. 
Mumon Ekai (Wu-men Hui-k'ai) (1994/2000): Mumonkan (1228), ed. by Eshin Nishimura, Tokyo: Iwanami Bunko; English version included in: Gateless Gate, Translated with Commentary by Zen master Kōun Yamada, 2nd ed., Tucson: University of Arizona Press, 1990.

Whitman, Walt (1973): Leaves of Grass (A Norton critical edition), ed. by Sculley Bradley and Harold W. Blodgett, New York \& London: Norton \& Co. 